\title{
Perilaku Kuat Tekan Beton Normal Terhadap Penambahan Serat Botol Plastik Jenis PET
}

\author{
Noviyanthy Handayani*1, Amelia Faradila ${ }^{2}$, Imam Juari ${ }^{3}$, Dian Larasati ${ }^{4}$ \\ 1,2,3,4 Universitas Muhammadiyah Palangkaraya, Jln. RTA Milono Km. 1,5 Palangka Raya \\ Program Studi Teknik Sipil, Fakultas Teknik dan Informatika, Palangka Raya \\ E-mail :*1.noviyanthy.handayani@umpalangkaraya.ac.id
}

Received 09 October 2020; Reviewed 14 October 2020; Accepted 15 March 2021

Journal Homepage: http://jurnal.borneo.ac.id/index.php/borneoengineering

\begin{abstract}
The Polyethylene Terephthalate (PET) plastic bottle waste was a material that took a long time to be decomposed and accumulated in earth for a long time. Therefore we need the utilization of the plastic waste. The one way to reuse the PET plastic bottle waste had to use it as an additive for the concrete mixture. The purpose of this study had to determine how much increase in the compressive strength of concrete $\left(f^{\prime} c\right)$ to the addition of the fiber PET plastic at 28 days of concrete. The variations in the addition of correspondently $0 \%, 0,2 \%, 0,4 \%, 0,6 \%, 0,8 \%$, and $1 \%$ to the volume of concrete cylinders within 3 samples of the concrete variations. The results showed that the concrete with the addition of PET fibers by $0.2 \%$ experienced an increase in the compressive strength value of $1.31 \%$ then the compressive strength of normal concrete which was originally 22.25 MPa to 22.65 MPa. In another hand, the variation of $0.4 \%, 0.6 \%, 0.8 \%$ and $1 \%$ PET decreased the compressive strength ( $\left.f^{\prime} c\right)$ of the concrete. The PET fiber concrete $0.6 \%$ and $1.0 \%$, although there was a decreased in the average compressive strength of the concrete, the value obtained exceeds the compressive strength value of the concrete mix design, which was 20 $M P a$.
\end{abstract}

Keywords : concrete fiber, concrete compressive strength, Polyethylene Terephthalate (PET)

\begin{abstract}
Abstrak
Limbah botol plastik Polyethylene Terephthalate (PET) adalah material yang membutuhkan waktu yang lama untuk terurai dan akan menumpuk di bumi dalam waktu yang lama. Oleh karena itu diperlukan suatu pemanfaatan dari sampah plastik tersebut. Salah satu cara pemanfaatan kembali limbah botol plastik PET ini yaitu digunakan sebagai bahan tambahan pada campuran beton. Tujuan dari penelitian ini yaitu untuk mengetahui seberapa besar peningkatan kuat tekan beton $\left(f^{\prime} c\right)$ terhadap penambahan cacahan limbah botol plastik PET pada umur beton 28 hari. Adapun variasi penambahan $0 \%, 0,2 \%, 0,4 \%, 0,6 \%, 0,8 \%$ dan $1 \%$ terhadap volume silinder beton dengan masing-masing 3 sampel setiap variasi beton. Hasil penelitian menunjukkan bahwa beton dengan penambahan serat PET sebesar 0,2\% mengalami peningkatan nilai kuat tekan sebesar 1,31\% dari kuat tekan beton normal yang semula 22,251 MPa menjadi 22,650 MPa. Sedangkan pada variasi persentase PET 0,4\%, 0,6\%, 0,8\% dan 1\% mengalami penurunan nilai kuat tekan beton (f'c). Pada beton serat PET 0,6\% dan 1,0\% walaupun terjadi penurunan nilai kuat tekan beton rata-rata tetapi nilai yang diperoleh melebihi nilai kuat tekan beton rencana yaitu sebesar $20 \mathrm{MPa}$.
\end{abstract}

Kata kunci : beton serat, kuat tekan beton, Polyethylene Terephthalate (PET) 


\section{Pendahuluan}

Limbah botol plastik Polyethylene Terephthalate (PET) adalah material yang membutuhkan waktu yang lama untuk terurai dan akan menumpuk di dunia dalam waktu yang lama. Mengutip dari BBC (08-08-2019) jumlah sampah plastik yang ada di dunia saat ini sudah mencapai angka 300 juta ton dalam setahun yang jika dipadatkan akan sama dengan 10 kali keliling bumi (Tim Publikasi Katadata, 2019). Oleh karena itu diperlukan suatu pemanfaatan dari sampah plastik tersebut. Menurut Akhmad Zainal, seperti yang dikutip dari artikel Jonathan Patrick dari CNN Indonesia, botol plastik jenis PET $100 \%$ bisa didaur ulang sehingga bisa meningkatkan pendapatan masyarakat.

Salah satu cara pemanfaatan kembali limbah botol plastik PET ini yaitu digunakan sebagai bahan tambahan pada campuran beton. Yosi (2019) melakukan penelitian dengan perbandingan berat isi beton serta kuat tekan beton antara beton dengan persentase 1\%, 2\% dan 3\% serat botol plastik PET sebagai pengganti agregat halus pada beton dan beton dengan campuran normal. Sampel beton dibuat dengan bentuk silinder dan dimensinya adalah $11 \mathrm{~cm} \times 22 \mathrm{~cm}$ dengan mutu rencana $25 \mathrm{MPa}$. Sampel diuji pada hari ke 7, 14 dan 28 hari. Hasil penelitian menunjukkan penurunan berat isi maksimum berkisar $1 \%-4 \%$ dan penurunan berat isi maksimum terjadi pada penggunaan serat plastik PET sebesar 3\%. Kuat tekan beton pada hari ke-28 dengan penggunaan serat plastik sebanyak $1 \%$ mencapai $16,48 \mathrm{MPa}$ dan meningkat sebesar 23,684\% dibandingkan beton normal. Elsi (2019) menambahkan plastik Polyethylene Terephthalate (PET) yang sudah dipotong menjadi serat berukuran 1-3 mm dengan panjang 2,5 $\mathrm{cm}$ pada adukan beton. Variasi persentase serat yang ditambahkan pada adonan beton adalah $0,25 \%, 0,5 \%, 1 \%$ serta $0 \%$ sebagai pembanding. Beton dengan penambahan serat dari plastik PET akan mengalami peningkatan nilai kuat tekan dibanding dengan beton tanpa penambahan serat. Penambahan serat PET sebanyak 0,25\% memberi peningkatan sebesar $1,31 \%$ dari beton normal. Penelitian yang sama juga dilakukan Andika dkk (2019) degan melakukan penambahan serat plastik PET sebesar 0,8\%, 1\%, dan 1,2\% dengan lebar serat plastik $0,3-0,5 \mathrm{~cm}$ dan panjang $5 \mathrm{~cm}$. Dari hasil penelitian tersebut didapatkan kenaikan kuat lentur pada beton dengan penambahan serat PET 0,8\% dan $1 \%$ mengalami kenaikan sebesar 11,81 MPa dan 12,23 MPa dibandingkan dengan beton normal tanpa campuran serat PET sebesar 11,18 MPa. Tetapi untuk beton dengan penambahan serat PET 1,2\% mengalami penurunan menjadi 11,02\% dibandingkan dengan beton normal tanpa campuran serat PET.

Merujuk beberapa hasil penelitian tersebut yang menunjukkan pemanfaatan limbah plastik PET maka penelitian ini dilaksanakan dengan tujuan untuk mengetahui seberapa besar peningkatan kuat tekan beton terhadap penambahan cacahan limbah botol plastik PET pada umur beton 28 hari. Adapun variasi penambahan $0 \%, 0,2 \%, 0,4 \%, 0,6 \%, 0,8 \%$ dan $1 \%$ terhadap volume silinder beton dengan masing-masing 3 sampel setiap variasi beton. Selain pemanfaatan limbah plastik PET, penelitian ini juga memperhatikan air campuran beton dan perawatan beton yang memiliki $\mathrm{pH}$ berkisar 5-7 atau kondisi asam-netral sesuai kondisi air yang berada di kota Palangka Raya Kalimantan Tengah, dimana air pada kondisi asam bisa mengakibatkan pengeroposan beton.

\section{Metode Penelitian}

\subsection{Pembuatan Sampel Beton}

Beton yang digunakan dalam pengujian adalah beton normal dengan kuat tekan rencana ( $\mathrm{f}^{\prime} \mathrm{c}=20$ $\mathrm{MPa}$ ). Benda Uji dibuat berupa benda uji beton silinder dengan diameter $15 \mathrm{~cm}$ dan tinggi $30 \mathrm{~cm}$. Rincian jumlah benda uji beton disajikan dalam Tabel 1 . 
Tabel 1. Jumlah Benda Uji Beton

\begin{tabular}{cccc}
\hline No. & $\begin{array}{c}\text { Variasi Serat } \\
\text { PET }\end{array}$ & Umur Beton & $\begin{array}{c}\text { Jumlah benda } \\
\text { uji }\end{array}$ \\
\hline 1 & $0 \%$ & 28 hari & 3 buah \\
2 & $0,2 \%$ & 28 hari & 3 buah \\
3 & $0,4 \%$ & 28 hari & 3 buah \\
4 & $0,6 \%$ & 28 hari & 3 buah \\
5 & $0,8 \%$ & 28 hari & 3 buah \\
6 & $1,0 \%$ & 28 hari & 3 buah \\
\hline \multicolumn{5}{c}{ Total Benda Uji } \\
\hline
\end{tabular}

\subsection{Analisis Data}

Analisis yang dilakukan adalah analisis hubungan antara variasi serat PET terhadap campuran beton, dengan mengacu pada :

1. Slump test.

2. Berat jenis beton normal akibat penambahan serat limbah botol plastik.

3. Derajat keasaman air campuran beton.

4. Kuat tekan beton.

\section{Hasil Dan Pembahasan}

\subsection{Hasil Pemeriksaan Agregat Penyusun Beton}

Material penyusun campuran beton serat merupakan material yang digunakan dalam pembuatan beton normal dengan tambahan plastik PET yang merupakan material limbah olahan, seperti disajikan pada Tabel 2 dan hasil pengujian untuk material penyusun beton disajikan pada Tabel 3 .

Tabel 2. Material Penyusun Beton

\begin{tabular}{|c|c|c|}
\hline No & Material & Sumber \\
\hline 1 & Semen & PC merk Gresik tipe 1 \\
\hline 2 & Agregat Halus & Pasir Tangkiling \\
\hline 3 & Agregat Kasar & Batu Pecah ex. Merak \\
\hline 4 & Air & Laboratorium Struktur \\
\hline 5 & Plastik PET & Limbah \\
\hline
\end{tabular}

Tabel 3. Hasil Pengujian Karakteristik Material Penyusun Beton

\begin{tabular}{lccc}
\hline \multicolumn{1}{c}{ Jenis Pemeriksaan } & Agregat Kasar & Agregat halus & Standar \\
\hline Kadar air (\%) & 2,34 & 0,03 & \\
Berat Jenis (gr/cm ${ }^{3}$ ) & & & \\
a. Specific gravity (apparent) & 2,62 & 2,68 & $2,58-2,84$ \\
b. Specific gravity (bulk) & 2,48 & 2,64 & $2,58-2,85$ \\
c. Specific gravity (SSD) & 2,54 & 2,66 & $2,58-2,86$ \\
d.Penyerapan air (\%) & 2,15 & 0,50 & $2,00-7,00$ \\
Keausan (\%) & 33,27 & - & $<40$ \\
\hline
\end{tabular}

Sumber : Hasil Penelitian (2020)

Menurut ASTM C-556 standar kadar air untuk agregat kasar adalah 0-3\% dan agregat halus 0-1\%, sehingga berdasarkan hasil pemeriksaan pada Tabel 3 kadar airnya telah memenuhi standar yang 
ada. Sedangkan pengujian berat jenis dan penyerapan air pada agregat kasar dan agregat halus mengacu pada SNI 1969-2008 dan SNI 1970-2008.

\subsection{Hasil Pemeriksaan Slump Test}

Pengujian slump beton mengacu pada SNI 1972:2008 tentang cara uji slump beton. Dari hasil pembuatan sampel beton kemudian dilakukan pengujian slump untuk mengetahui tingkat workability beton yang akan dicampurkan dengan variasi campuran PET yang berbeda untuk umur beton 28 hari. Nilai slump yang dihasilkan dari campuran beton segar dapat dilihat pada Tabel 4 .

Tabel 4. Nilai Slump Test

\begin{tabular}{cccl}
\hline Tanggal Cetak & Umur & Nilai Slump $(\mathrm{cm})$ & Rencana Campuran Beton PET \\
\hline $25-07-2020$ & 28 hari & 7,75 & Beton PET 0,0\% \\
$29-07-2020$ & 28 hari & 9,00 & Beton PET 0,2\% \\
$29-07-2020$ & 28 hari & 9,00 & Beton PET 0,4\% \\
$26-07-2020$ & 28 hari & 6,25 & Beton PET 0,6\% \\
$26-07-2020$ & 28 hari & 6,25 & Beton PET 0,8\% \\
$29-07-2020$ & 28 hari & 6,10 & Beton PET $1,0 \%$ \\
\hline
\end{tabular}

Sumber : Hasil Penelitian (2020)

Berdasarkan Tabel 4 terlihat bahwa untuk campuran beton yang direncanakan untuk pencampuran PET 0\% atau beton normal memiliki nilai slump $7,75 \mathrm{~cm}$. Sedangkan untuk beton yang direncanakan untuk campuran PET sebesar 0,2\% dan 0,4\% memiliki nilai slump tertinggi, yaitu 9 $\mathrm{cm}$. Sedangkan untuk campuran beton yang direncanakan dengan $0,6 \%, 0,8 \%$, dan $1,0 \%$ nilai slump yang dihasilkan justru semakin kecil, yaitu $6,25 \mathrm{~cm}$ dan $6,10 \mathrm{~cm}$. Hal ini merupakan pengaruh dari proses pencampuran beton di concrete mixer. Pembuatan sampel dan pencampuran pada mesin concrete mixer hanya bisa dilakukan untuk 6 sampel beton, sehingga menimbulkan perbedaan nilai slump untuk masing-masing adukan beton segar. Penambahan PET dilakukan pada saat campuran beton dimasukkan ke dalam cetakan silinder yang dilakukan secara bertahap perlapis dan kemudian diratakan menggunakan concrete vibrator.

\subsection{Derajat Keasaman (pH) Air}

Air yang digunakan untuk proses pembuatan dan proses perawatan sampel beton berasal dari air ledeng yang mengalir pada laboratorium Struktur Fakultas Teknik dan Informatika UM Palangkaraya. Hasil pengukuran $\mathrm{pH}$ air tersebut yaitu 5,0 - 6,0 yang menunjukkan kualitas dalam keadaan asam, terlihat pada Gambar 2 dan 3 berikut: 


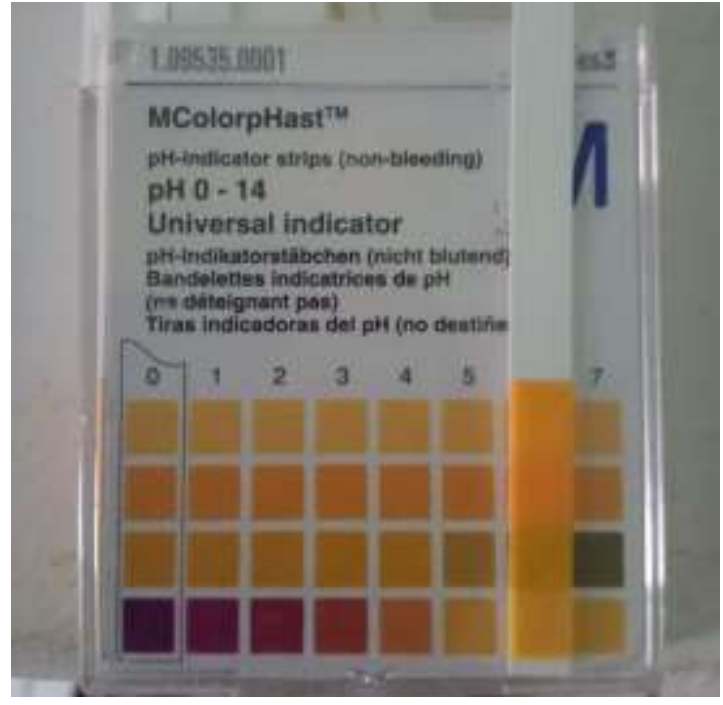

Gambar 2. Hasil pengukuran air campuran beton

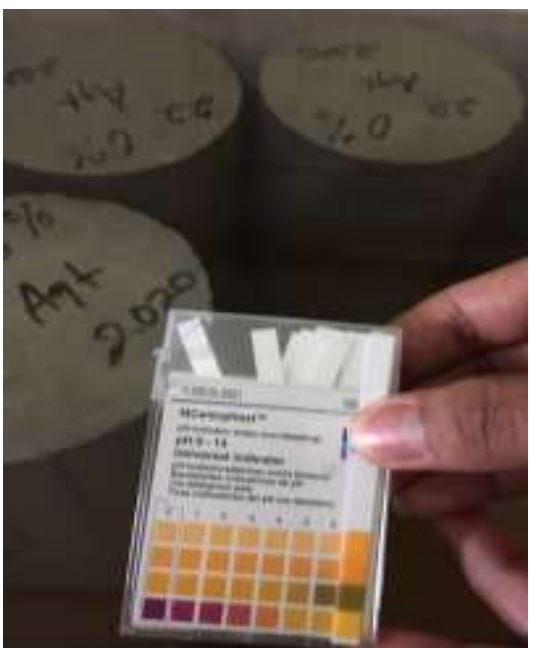

Gambar 3. Hasil pengukuran $\mathrm{pH}$ air perawatan beton

Gambar 2 menunjukkan pH air 5,0 hal ini disebabkan pengukuran langsung di sumber air tanpa ada proses pengendapan terlebih dahulu. Sedangkan pada Gambar $4.2 \mathrm{pH}$ air perawatan menunjukkan 6,0 hal ini karena beton yang direndam pada air yang sudah mengalami oksidasi sehingga mempengaruhi $\mathrm{pH}$ air rendaman. Air rendaman ini selalu berganti tiap 3 hari sekali untuk menstabilkan $\mathrm{pH}$ air berkisar diantara 5,0 - 7,0 dalam kondisi asam mendekati netral. Air dalam kondisi basa atau tidak pernah berganti selama proses perawatan beton 28 hari, cenderung basa dan bisa meningkatkan nilai kuat tekan beton. Hal ini ditunjukkan oleh penelitian Handayani (2018) dan Saputra, dkk (2020) yang melakukan penelitian beton yang direndam di air ledeng tanpa pergantian air menunjukkan peningkatan nilai kuat tekan beton yang sebanding dengan lamanya waktu perendaman.

\subsection{Desain Campuran Beton}

Sampel beton yang dibuat berdasarkan Tabel 3 yaitu sebanyak 18 buah dengan masing-masing persen campuran limbah plastik PET sebanyak 3 buah. Desain campuran beton yang digunakan mengacu pada SNI 03-2834-2000. Jumlah berat dan persentase limbah serat PET dapat dilihat pada Tabel 5. 
Tabel 5. Variasi serat PET

\begin{tabular}{ccccc}
\hline No. & Variasi Serat PET & Berat Limbah Serat PET (gram) & Umur Beton & Jumlah benda uji \\
\hline 1 & $0 \%$ & 0 & 28 hari & 3 buah \\
2 & $0,2 \%$ & 12,05 & 28 hari & 3 buah \\
3 & $0,4 \%$ & 24,11 & 28 hari & 3 buah \\
4 & $0,6 \%$ & 36,16 & 28 hari & 3 buah \\
5 & $0,8 \%$ & 48,21 & 28 hari & 3 buah \\
6 & $1,0 \%$ & 60,28 & 28 hari & 3 buah \\
\hline \multicolumn{5}{c}{ Total Benda Uji } \\
\hline
\end{tabular}

Berat limbah serat PET yang digunakan seperti tercantum pada Tabel 5 dihitung berdasarkan berat semen yang digunakan dalam campuran beton.

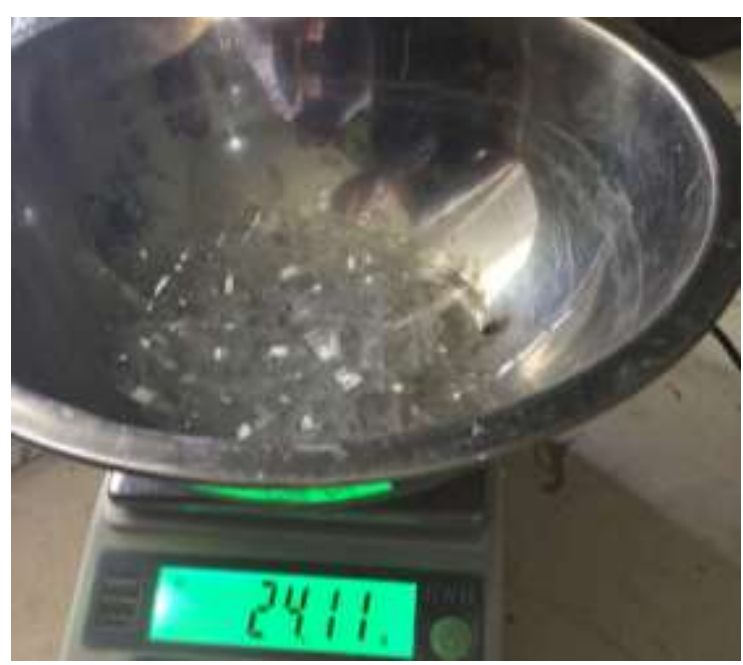

Gambar 4. Limbah plastik PET

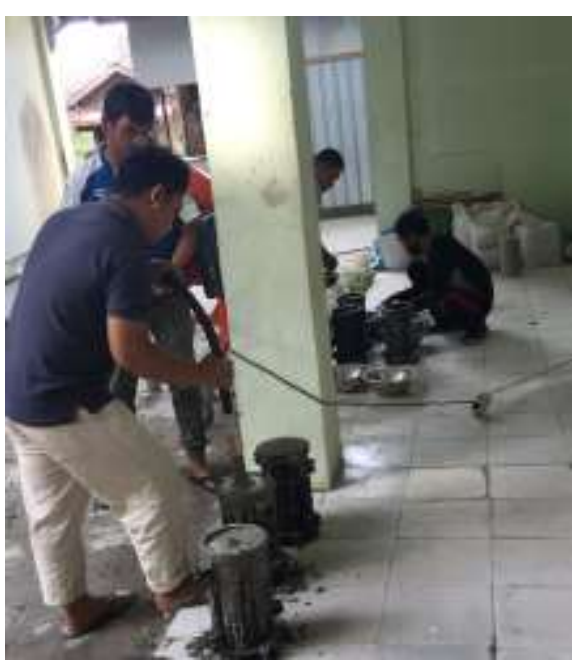

Gambar 5. Proses pembuatan sampel beton PET

Adapun design mix formula (DMF) yang digunakan pada pembuatan beton serat PET ini dapat dilihat pada Tabel 6 .

Tabel 6. DMF Beton Serat PET

\begin{tabular}{cccc}
\hline Air $(\mathbf{k g})$ & Semen $(\mathbf{k g})$ & Agregat Halus $(\mathbf{k g})$ & Agregat Kasar $(\mathbf{k g})$ \\
\hline \multicolumn{4}{c}{ Untuk 1 } \\
1,38 & 2,80 & silinder beton \\
& Untuk 1 adukan beton (9 silinder beton) & 6,00 \\
12,42 & 25,21 & 35,75 & 53,98 \\
\hline
\end{tabular}

\subsection{Nilai Hasil Kuat Tekan Beton Serat}

Hasil nilai kuat beton serat PET pada umur beton 28 hari dapat dilihat pada Tabel 7 dimana uji kuat tekan beton mengacu pada SNI 1974:2011. 
Tabel 7. Nilai Kuat Tekan Beton Serat PET

\begin{tabular}{|c|c|c|c|c|c|c|c|}
\hline $\begin{array}{l}\text { Tipe } \\
\text { Beton }\end{array}$ & $\begin{array}{c}\text { Tanggal } \\
\text { Cetak }\end{array}$ & $\begin{array}{c}\text { Tanggal } \\
\text { Uji }\end{array}$ & $\begin{array}{l}\text { Umur } \\
\text { (hari) }\end{array}$ & Berat $(\mathrm{kg})$ & $\begin{array}{c}\text { Luas } \\
\text { penampang } \\
\left(\mathrm{cm}^{2}\right)\end{array}$ & $\begin{array}{c}\text { Kuat } \\
\text { Tekan } \\
(\mathrm{KN})\end{array}$ & $\begin{array}{l}\text { Kuat } \\
\text { Tekan } \\
\text { (f'c) } \\
\text { (MPa) }\end{array}$ \\
\hline $\begin{array}{c}\text { Beton } \\
\text { PET 0\% }\end{array}$ & $\begin{array}{c}25-07- \\
2020\end{array}$ & $\begin{array}{c}22-08- \\
2020\end{array}$ & 28 & $\begin{array}{l}12,06 \\
12,15 \\
12,23\end{array}$ & $\begin{array}{l}176,79 \\
176,79 \\
176,79\end{array}$ & $\begin{array}{l}379,50 \\
396,20 \\
404,40\end{array}$ & $\begin{array}{l}21,46 \\
22,41 \\
22,88\end{array}$ \\
\hline $\begin{array}{l}\text { Beton } \\
\text { PET } \\
0,2 \%\end{array}$ & $\begin{array}{c}29-07- \\
2020\end{array}$ & $\begin{array}{c}26-08- \\
2020\end{array}$ & 28 & $\begin{array}{l}12,15 \\
12,21 \\
12,23\end{array}$ & $\begin{array}{l}176,79 \\
176,79 \\
176,79\end{array}$ & $\begin{array}{l}383,10 \\
397,80 \\
420,40\end{array}$ & $\begin{array}{l}21,67 \\
22,50 \\
23,78\end{array}$ \\
\hline $\begin{array}{l}\text { Beton } \\
\text { PET } \\
0,4 \%\end{array}$ & $\begin{array}{c}29-07- \\
2020\end{array}$ & $\begin{array}{c}26-08- \\
2020\end{array}$ & 28 & $\begin{array}{l}12,01 \\
12,25 \\
12,40\end{array}$ & $\begin{array}{l}176,79 \\
176,79 \\
176,79\end{array}$ & $\begin{array}{l}287,30 \\
318,70 \\
337,40\end{array}$ & $\begin{array}{l}16,25 \\
18,03 \\
19,08\end{array}$ \\
\hline $\begin{array}{l}\text { Beton } \\
\text { PET } \\
0,6 \%\end{array}$ & $\begin{array}{c}26-07- \\
2020\end{array}$ & $\begin{array}{c}23-08- \\
2020\end{array}$ & 28 & $\begin{array}{l}12,47 \\
12,32 \\
12,19\end{array}$ & $\begin{array}{l}176,79 \\
176,79 \\
176,79\end{array}$ & $\begin{array}{l}323,30 \\
340,00 \\
450,50\end{array}$ & $\begin{array}{l}18,28 \\
19,23 \\
25,48\end{array}$ \\
\hline $\begin{array}{l}\text { Beton } \\
\text { PET } \\
0,8 \%\end{array}$ & $\begin{array}{c}26-07- \\
2020\end{array}$ & $\begin{array}{c}23-08- \\
2020\end{array}$ & 28 & $\begin{array}{l}12,31 \\
12,34 \\
12,30\end{array}$ & $\begin{array}{l}176,79 \\
176,79 \\
176,79\end{array}$ & $\begin{array}{l}325,30 \\
346,70 \\
383,50\end{array}$ & $\begin{array}{l}18,40 \\
19,61 \\
21,69\end{array}$ \\
\hline $\begin{array}{l}\text { Beton } \\
\text { PET } \\
1,0 \%\end{array}$ & $\begin{array}{c}29-07- \\
2020\end{array}$ & $\begin{array}{c}26-08- \\
2020\end{array}$ & 28 & $\begin{array}{l}12,23 \\
12,14 \\
12,25\end{array}$ & $\begin{array}{l}176,79 \\
176,79 \\
176,79\end{array}$ & $\begin{array}{l}341,20 \\
372,60 \\
458,50\end{array}$ & $\begin{array}{l}19,30 \\
21,07 \\
25,94\end{array}$ \\
\hline
\end{tabular}

Sumber : Hasil Penelitian (2020)

Berdasarkan Tabel 7, dapat dibuat grafik perbandingan beton normal terhadap beton serat PET seperti yang ditunjukkan pada Gambar 6, Gambar 7, Gambar 8, Gambar 9, dan Gambar 10.

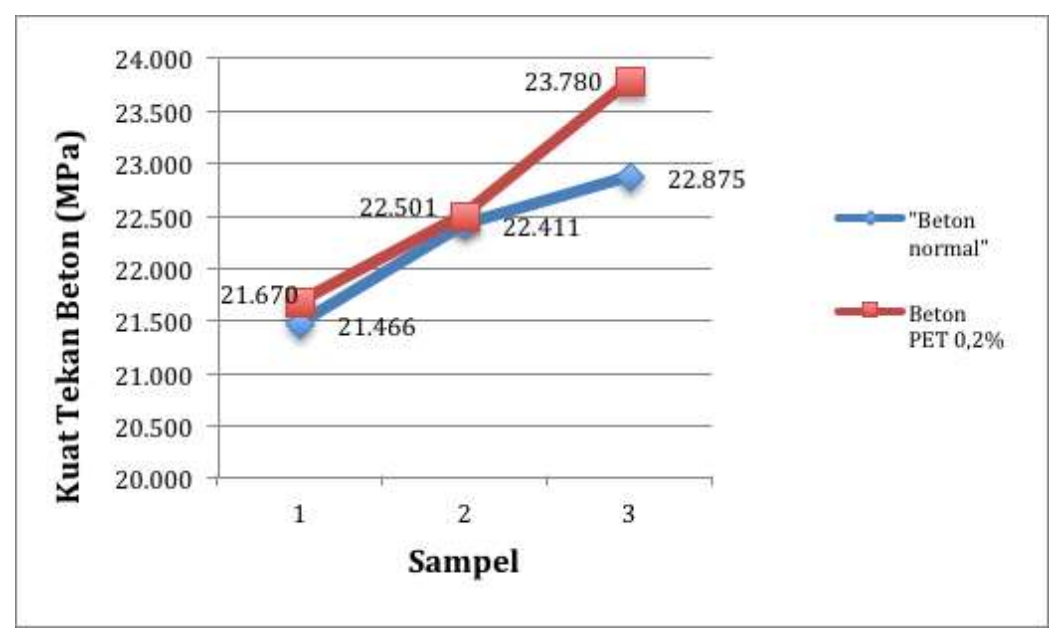

Gambar 6. Perbandingan Beton normal dan Beton PET 0,2\%

Pada Gambar 6 perbandingan beton normal (tanpa tambahan PET) dan beton serat PET 0,2\% terlihat bahwa nilai kuat tekan beton normal berada dibawah nilai kuat tekan beton normal. 


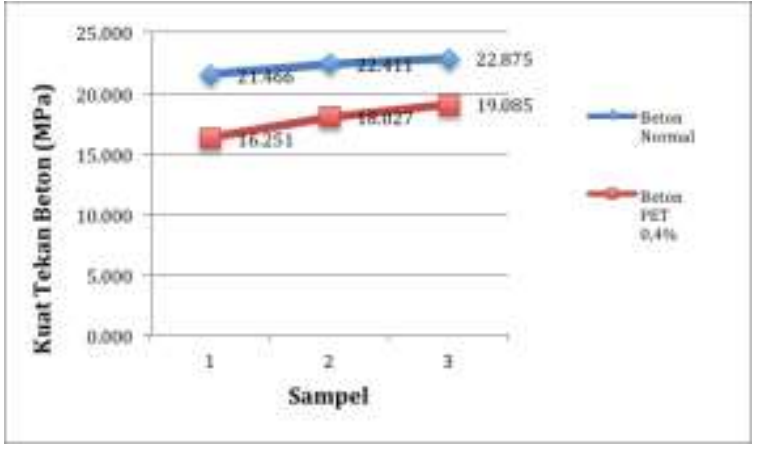

Gambar 7. Perbandingan beton normal dan beton PET $0,4 \%$

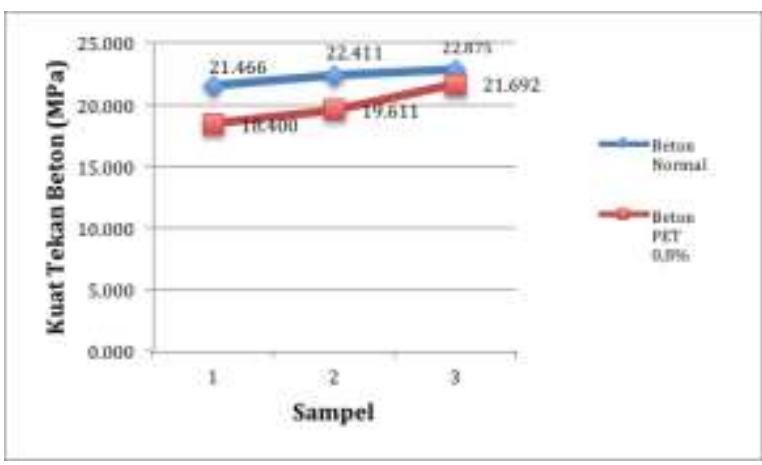

Gambar 9. Perbandingan beton normal dan beton PET $0,8 \%$

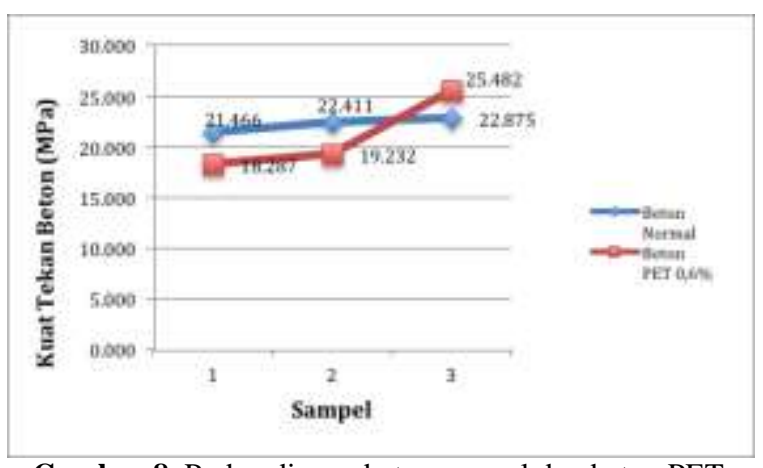

Gambar 8. Perbandingan beton normal dan beton PET $0,6 \%$

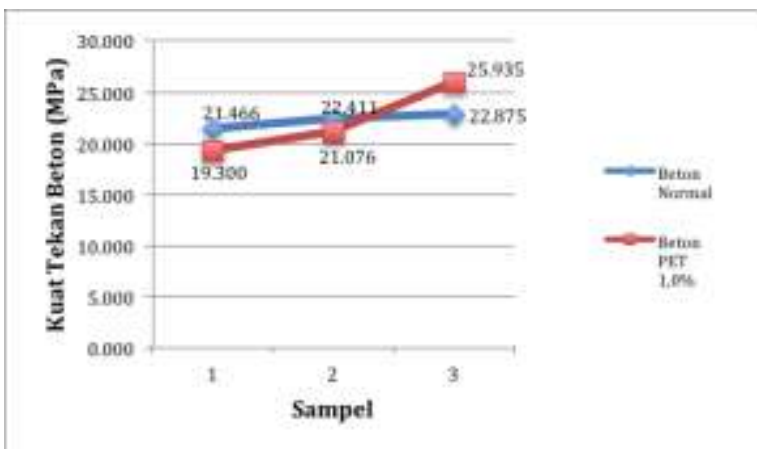

Gambar 10. Perbandingan beton normal dan beton PET $1,0 \%$

Sedangkan pada Gambar 7 sampai 10 menunjukkan nilai kuat tekan beton PET berada dibawah nilai kuat tekan beton normal walaupun di variasi $0,6 \%$ dan $1,0 \%$ ada satu sampel yang berada diatas beton normalnya.

\section{Tabel 8. Nilai Kuat Tekan Rata-rata}

\begin{tabular}{|c|c|c|c|c|c|c|}
\hline $\begin{array}{l}\text { Tipe } \\
\text { Beton }\end{array}$ & $\begin{array}{c}\text { Tanggal } \\
\text { Cetak }\end{array}$ & $\begin{array}{c}\text { Tanggal } \\
\text { Uji }\end{array}$ & Umur & $\begin{array}{l}\text { Kuat Tekan } \\
\quad(\mathrm{KN})\end{array}$ & $\begin{array}{l}\text { Kuat Tekan } \\
\left(\mathrm{f}^{\prime} \mathrm{c}\right)(\mathrm{MPa})\end{array}$ & $\begin{array}{c}\text { Kuat Tekan Rata- } \\
\text { rata }\left(\mathrm{f}^{\prime} \mathrm{c}\right)(\mathrm{MPa})\end{array}$ \\
\hline \multirow{3}{*}{$\begin{array}{l}\text { Beton } \\
\text { PET 0\% }\end{array}$} & \multirow{3}{*}{$\begin{array}{l}25-07- \\
2020\end{array}$} & \multirow{3}{*}{$\begin{array}{l}22-08- \\
2020\end{array}$} & \multirow{3}{*}{28 hari } & 379,50 & 21,47 & \multirow{3}{*}{22,25} \\
\hline & & & & 396,20 & 22,41 & \\
\hline & & & & 404,40 & 22,88 & \\
\hline \multirow{3}{*}{$\begin{array}{c}\text { Beton } \\
\text { PET } 0,2 \%\end{array}$} & \multirow{3}{*}{$\begin{array}{l}29-07- \\
2020\end{array}$} & \multirow{3}{*}{$\begin{array}{c}26-08- \\
2020\end{array}$} & \multirow{3}{*}{28 hari } & 383,10 & 21,67 & \multirow{3}{*}{22,65} \\
\hline & & & & 397,80 & 22,50 & \\
\hline & & & & 420,40 & 23,78 & \\
\hline \multirow{3}{*}{$\begin{array}{c}\text { Beton } \\
\text { PET } 0,4 \%\end{array}$} & \multirow{3}{*}{$\begin{array}{l}29-07- \\
2020\end{array}$} & \multirow{3}{*}{$\begin{array}{c}26-08- \\
2020\end{array}$} & \multirow{3}{*}{28 hari } & 287,30 & 16,25 & \multirow{3}{*}{17,79} \\
\hline & & & & 318,70 & 18,03 & \\
\hline & & & & 337,40 & 19,08 & \\
\hline \multirow{3}{*}{$\begin{array}{c}\text { Beton } \\
\text { PET } 0,6 \%\end{array}$} & \multirow{3}{*}{$\begin{array}{l}26-07- \\
2020\end{array}$} & \multirow{3}{*}{$\begin{array}{c}23-08- \\
2020\end{array}$} & \multirow{3}{*}{28 hari } & 323,30 & 18,28 & \multirow{3}{*}{21,00} \\
\hline & & & & 340,00 & 19,23 & \\
\hline & & & & 450,50 & 25,48 & \\
\hline \multirow{3}{*}{$\begin{array}{c}\text { Beton } \\
\text { PET } 0,8 \%\end{array}$} & \multirow{3}{*}{$\begin{array}{l}26-07- \\
2020\end{array}$} & \multirow{3}{*}{$\begin{array}{c}23-08- \\
2020\end{array}$} & \multirow{3}{*}{28 hari } & 325,30 & 18,40 & \multirow{3}{*}{19,90} \\
\hline & & & & 346,70 & 19,61 & \\
\hline & & & & 383,50 & 21,69 & \\
\hline \multirow{3}{*}{$\begin{array}{c}\text { Beton } \\
\text { PET } 1,0 \%\end{array}$} & \multirow{3}{*}{$\begin{array}{l}29-07- \\
2020\end{array}$} & \multirow{3}{*}{$\begin{array}{c}26-08- \\
2020\end{array}$} & \multirow{3}{*}{28 hari } & 341,20 & 19,30 & \multirow{3}{*}{22,10} \\
\hline & & & & 372,60 & 21,07 & \\
\hline & & & & 458,50 & 25,94 & \\
\hline
\end{tabular}

Sumber : Hasil Penelitian (2020) 
Dari Tabel 8 diatas apabila dapat dibuat grafik perbandingan nilai kuat tekan rata-rata seperti terlihat pada Gambar 11 berikut:

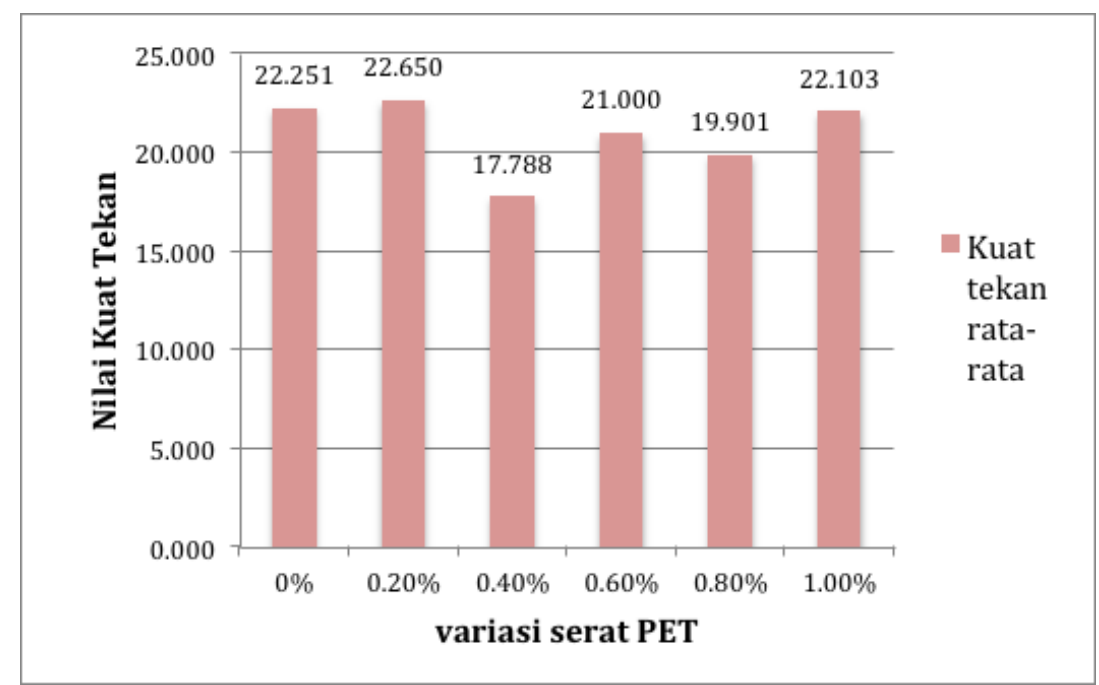

Gambar 11. Kuat tekan rata-rata beton serat PET

Pada Gambar 11 terlihat bahwa beton serat PET yang mengalami penurunan dari kuat tekan beton rencana $20 \mathrm{MPa}$ terjadi pada variasi penambahan $0,4 \%$ dan $0,8 \%$, yaitu sebesar $17,79 \mathrm{MPa}$ dan 19,901 MPa. Sedangkan beton serat PET 0,2\% mengalami kenaikan 1,80\% dari beton tanpa serat PET yaitu sebesar 0,4 MPa, dari semula 22,25 MPa menjadi 22,65 MPa.

Dari Gambar 11 juga terlihat bahwa beton serat PET 0,6\% dan 1,0\% mengalami penurunan nilai kuat tekan dari beton tanpa serat PET. Tetapi nilai kuat tekan yang diperoleh masih diatas dari kuat tekan beton rencana yaitu sebesar $20 \mathrm{MPa}$.

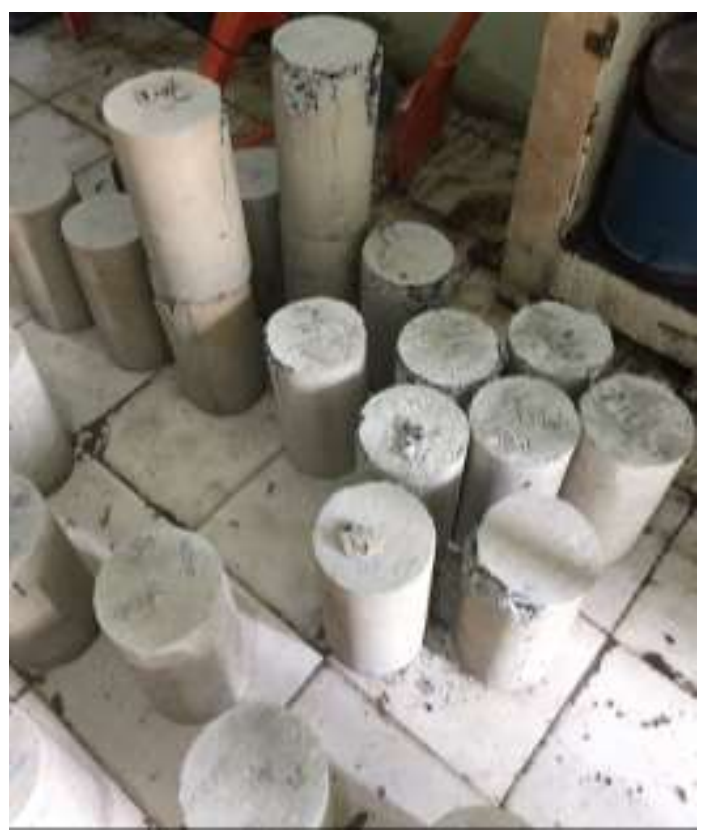

Gambar 12. Sampel beton yang sudah diuji kuat tekan 


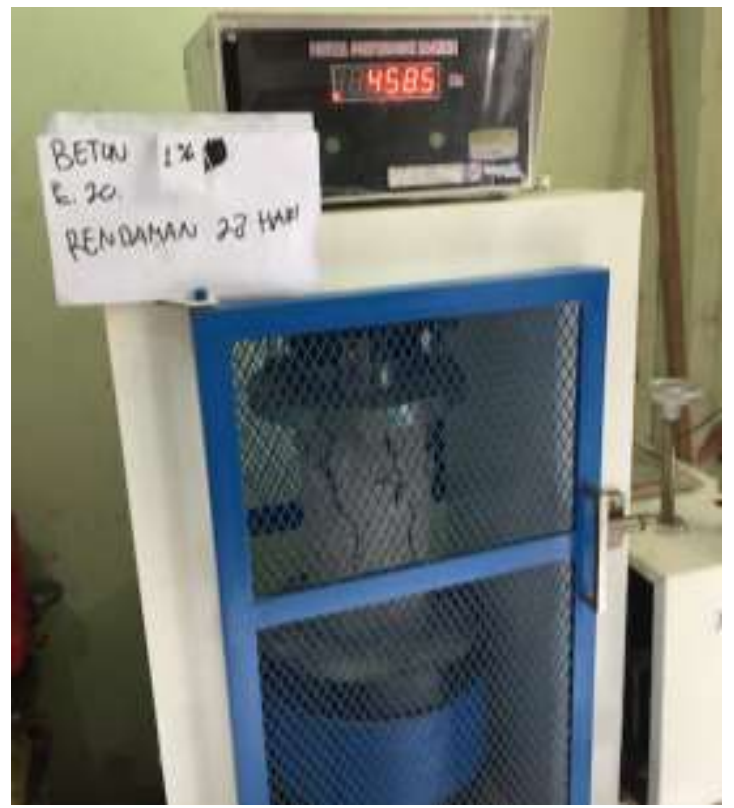

Gambar 13. Proses uji kuat tekan beton

Apabila ditinjau dari berat isi maksimum beton, maka dapat dilihat pada Tabel 9 berikut ini:

Tabel 9. Berat Isi Maksimum Beton

\begin{tabular}{ccc}
\hline Tipe Beton & $\begin{array}{c}\text { Berat } \\
(\mathrm{kg})\end{array}$ & $\begin{array}{c}\text { Berat rata-rata } \\
(\mathrm{kg})\end{array}$ \\
\hline \multirow{2}{*}{$0,0 \%$} & 12,06 & 12,15 \\
& 12,15 & \\
$0,2 \%$ & 12,23 & 12,19 \\
& 12,15 & \\
& 12,21 & 12,22 \\
$0,4 \%$ & 12,23 & \\
& 12,01 & 12,33 \\
$0,6 \%$ & 12,25 & \\
& 12,40 & 12,32 \\
$0,8 \%$ & 12,47 & \\
& 12,32 & \\
& 12,19 & 12,20 \\
\hline & 12,31 & \\
\hline
\end{tabular}

Sumber : Hasil Penelitian (2020)

Dari Tabel 9 diatas, apabila dibuat tabel perbandingan berat isi maksimum rata-rata untuk setiap variasi dapat dilihat pada Gambar 14.

Dari Tabel 9 dan Gambar 14, terlihat bahwa dengan adanya penambahan limbah plastik PET akan menambah berat isi maksimum beton. Penambahan maksimum terjadi pada variasi limbah PET $0,6 \%$ yaitu sebesar $1,46 \%$ bila dibandingkan dengan berat isi beton normal. 


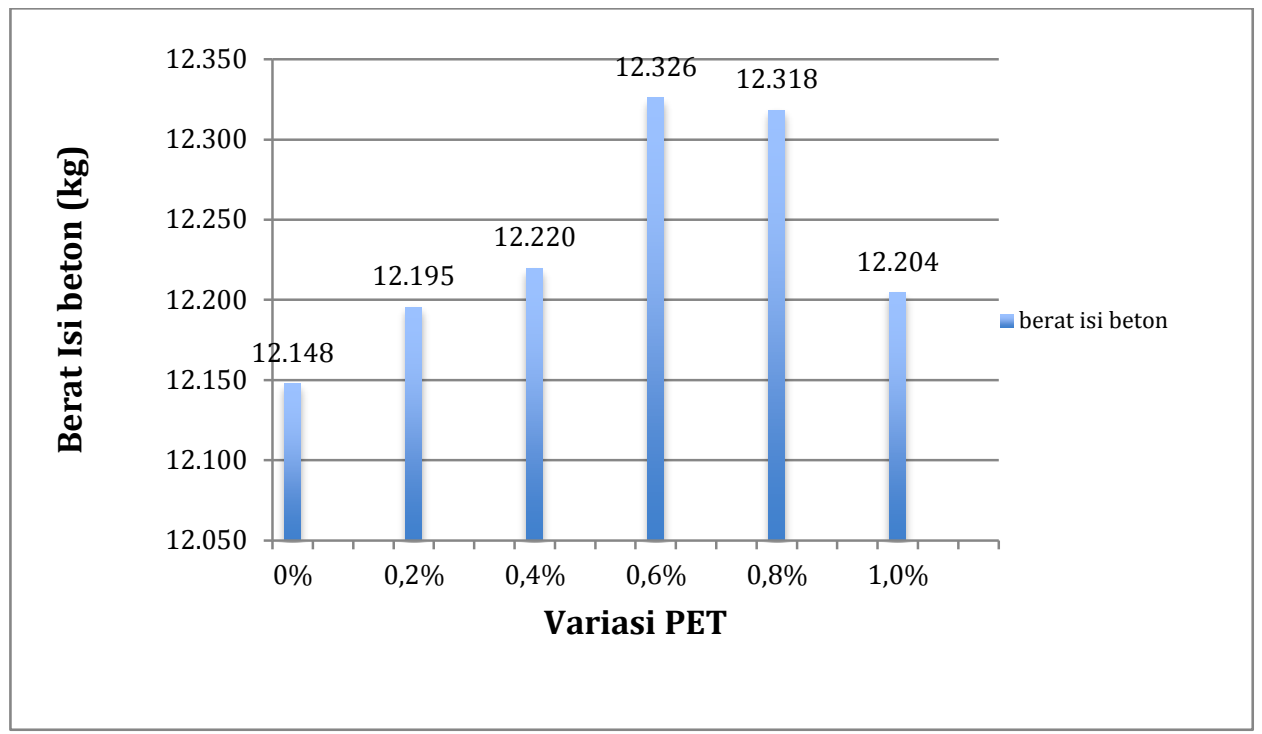

Gambar 14. Perbandingan berat isi beton rata-rata

Dari hasil penelitian yang dilakukan untuk penambahan limbah PET sebesar $0,2 \%$ terjadi peningkatan kuat tekan beton sebesar $1,80 \%$ dari nilai kuat tekan beton normal. Namun pada variasi penambahan limbah PET sebesar $1 \%$ terjadi penurunan kuat tekan beton sebesar $0,66 \%$ dari kuat tekan beton normal yaitu 22,25 MPa menjadi 22,10 MPa. Elsi (2019) melakukan penelitian yang sama dengan menambahkan plastik PET pada campuran beton tetapi dengan variasi yang berbeda, yaitu $0,25 \%, 0,5 \%, 1 \%$ dan tanpa tambahan apapun terhadap beton normal $(0 \%)$. Dari hasil penelitian tersebut diperoleh hasil nilai kuat tekan yang meningkat untuk variasi $0,25 \%$ sebesar $1,31 \%$ dari beton normal dan pada variasi $1 \%$ mengalami kenaikan sebesar $4,17 \%$.

Pada penelitian ini juga dapat dilihat pengaruh penambahan serat limbah PET terhadap berat isi beton dimana penggunaan serat botol plastik PET meningkatkan berat isi beton sebesar 1,46\% dibandingkan dengan beton normal. Hal ini berbeda dengan penelitian yang dilakukan Yosi (2019), dimana untuk perbandingan berat isi beton dengan penambahan serat botol PET sebesar 1\%, 2\%, dan 3\% terhadap beton normal, terjadi penurunan berat isi beton sebesar 1-4\%.

\section{Kesimpulan}

Berdasarkan hasil penelitian dapat diperoleh kesimpulan pengaruh penambahan serat PET terhadap kuat tekan beton dapat dilihat pada beton dengan penambahan serat PET sebanyak 0,2\% dan 0,4\% dan juga beton dengan tambahan serat PET 0,6\% dan 0,8\%. Dari hasil bacaan kuat tekan terlihat bahwa untuk beton dengan tambahan PET sebanyak 0,2\% memiliki kuat tekan yang lebih besar dari beton dengan tambahan PET 0,4\%. Begitu juga dengan beton yang memiliki tambahan PET $0,6 \%$ dan $0,8 \%$ yang juga dibuat bersamaan, beton dengan tambahan PET 0,6\% memiliki kuat tekan yang lebih besar dari beton dengan tambahan PET 0,8\%. Sehingga dengan adanya penambahan serat PET untuk sampel yang dibuat secara bersamaan akan memperkecil nilai kuat tekan beton tersebut. Kendala yang dihadapi pada saat pengerjaan percobaan ini adalah sampel beton yang digunakan tidak semuanya bisa dibuat secara bersamaan untuk seluruh penambahan serat PET yang direncanakan karena terbatasnya kapasitas concrete mixer, sehingga pembuatan campuran beton dibagi menjadi beberapa tahapan, yang mana untuk satu kali campuran hanya dapat menghasilkan 6 sampel. 


\section{Ucapan Terima Kasih}

Penelitian ini dapat dilaksanakan karena bantuan dari Program Penelitian Kompetitif Dosen Internal (PKDI) Lembaga Penelitian dan Pengabdian Kepada Masyarakat Universitas Muhammadiyah Palangkaraya TA. 2020.

\section{Daftar Pustaka}

American Standard Testing and Material Chapter 556. Standard Test for Water Vapor Transmission of materials.

Elsi, M. 2019. Pengaruh Penggunaan Botol Plastik Polyethylene Terephthalate (PET) Sebagai Tambahan Serat Terhadap Kekuatan Beton. Doctoral dissertation Universitas Andalas http://scholar.unand.ac.id/id/eprint/54517

Handayani, Noviyanthy. 2018. Ketahanan Beton Normal Terhadap Air Gambut di Kota Palangka Raya. Media Ilmiah Teknik Sipil Vol. 7 No.1. https://doi.org/10.33084/mits.v7i1.684

Patrick, Jonathan. 2019. Sampah Plastik, Dilema Krisis Lingkungan atau Cuan Ekonomi. https://www.cnnindonesia.com/teknologi/20191127074615-199-451822/sampah-plastik-dilemakrisis-lingkungan-atau-cuan-ekonomi

Saputra, N., \& Handayani, N. 2020. Ketahanan Beton f'c 22,5 MPa Terhadap Kondisi Air Kota Palangka Raya. Rekayasa Sipil, 14(2), pp.91 - 98.

https://rekayasasipil.ub.ac.id/index.php/rs/article/view/670

Setiawan, Andika and Masagala, Algazt Aryad. 2019. Pengaruh Penambahan Serat Limbah Plastik Polyethylene Terephthalate (Pet) Dengan Persentase 0,8\%, 1\%, dan 1,2\% Pada Beton Bertulang Terhadap Kuat Lentur. Tugas Akhir thesis, University Technology Yogyakarta. http://eprints.uty.ac.id/2801

Standar Nasional Indonesia 03-2834-2000. Tata Cara Pembuatan Rencana Campuran Beton Normal. Badan Standarisasi Nasional

Standar Nasional Indonesia 1969:2008. Cara Uji Berat Jenis dan Penyerapan Air Agregat Kasar. Badan Standarisasi Nasional.

Standar Nasional Indonesia 1970:2008. Cara Uji Berat Jenis dan Penyerapan Air Agregat Halus. Badan Standarisasi Nasional.

Standar Nasional Indonesia 1972:2008. Cara Uji Slump Beton. Badan Standarisasi Nasional.

Standar Nasional Indonesia 1974:2011. Cara Uji Kuat Tekan Beton dengan Benda Uji Silinder. Badan Standarisasi Nasional.

Tim Publikasi Katadata. 2019. Pentingnya Pengelolaan Sampah Plastik. https://katadata.co.id/berita/2019/11/08/pentingnya-pengelolaan-sampah-plastik

YOSI, J. N. 2019. Pengaruh Penggunaan Botol Plastik Polyethylene Terephthalate (PET) Sebagai Pengganti Agregat Halus Terhadap Kuat Tekan Beton. Doctoral dissertation, Universitas Andalas http://scholar.unand.ac.id/id/eprint/54516 